\title{
LEPTOSPIRA SPP DETECTION BY POLYMERASE CHAIN REACTION (PCR) IN CLINICAL SAMPLES OF CAPTIVE BLACK-CAPPED CAPUCHIN MONKEY (CEBUS APELLA)
}

\author{
Eliana Scarcelli*; Rosa Maria Piatti; José Daniel Luzes Fedullo; Faiçal Simon; Maristela Vasconcellos Cardoso; \\ Vanessa Castro; Simone Miyashiro; Margareth Élide Genovez
}

Centro de Pesquisa e Desenvolvimento de Sanidade Animal, Instituto Biológico, São Paulo, SP, Brasil.

Submitted: August 23, 2002; Returned to authors for corrections: March 16, 2003; Approved: May 26, 2003

\begin{abstract}
Leptospirosis is a widely distributed zoonosis that affects domestic and wild animals, and that has the man as the end point of its epidemiological chain. Leptospirosis diagnosis in primates is more difficult than in other animal species, as clinical signs and lesions are less evident and antibody response is detected only for short periods. The aim of this article was to describe the detection of Leptospira spp using polymerase chain reaction (PCR), in clinical samples from one captive black-capped Capuchin monkey (Cebus apella), which presented characteristics compatible with leptospirosis (jaundice and haemorrhagic kdney) in the macroscopic post-mortem examination. A friable kidney fragment and urine sample were cultured and submitted to experimental inoculation in guinea pigs and PCR using genus specific primer pair targeting the 16S rRNA region from Leptospira interrogans serovar canicola. Isolation of the agent was negative both in culture and experimental inoculation. The PCR amplification of the clinical samples showed a $330 \mathrm{pb}$ amplified fragment that corresponds to the Leptospira genus. Based on these results PCR was considered an important tool for leptospira detection in nonhumam primates, more sensitive and specific than other techniques, especially considering that the viability of the pathogen was not possible. These advantages enable the detection of the leptospiras in urine and kidney, even when autolysed, frozen or badly conserved, which prevented the isolation and experimental inoculation from positive results.
\end{abstract}

Key words: Leptospirosis, nonhuman primate, PCR, Cebus apella

\section{INTRODUCTION}

Leptospirosis is a widely distributed zoonosis that affects domestic and wild animals, and that has the man as the end point of its epidemiological chain. An infected animal may be assymptomatic, and during its whole life it may eliminate one of the 250 known serovars of the Leptospira genus in its urine (6). Leptospirosis symptoms observed in natural infection of nonhuman primates are normally mild and limited to febrile responses, conjunctivitis and restlessness (6), mostly unnoticed On the other hand, in experimental infections using different serovars, clinical signs may range from only fever response to serious clinical symptoms with high fever, acute depression, jaundice, and death, in some cases, with lesions in liver and kidney $(2,3)$.

Leptospirosis in nonhuman primates has become increasingly important for these animals that may become renal carriers of the pathogen, what makes them a risk for both zoo and laboratory animal facility workers, veterinarians, for other primates and animals. Primates may also be used as sources of primary cultures of kidney cells for laboratory diagnosis purposes, which may inadvertently transfer leptospires to the cell culture medium $(2,3)$.

Leptospirosis diagnosis in primates is more difficult than in other animal species, because clinical signs and lesions are less evident and antibody response is detected only for short periods (3).

\footnotetext{
* Corresponding author. Mailing address: Centro de Pesquisa e Desenvolvimento de Sanidade Animal, Instituto Biológico. Av. Conselheiro Rodrigues Alves, 1252. 04014-002, São Paulo, SP, Brasil. Telephone:(+ 5511) 5087-1770. E-mail: pinheiro@ biologico.sp.gov.br
} 
The aim of this article was to describe the use of PCR as an important tool for leptospirosis diagnosis in nonhuman primates, when no significant symptoms could be noticed.

\section{MATERIALS AND METHODS}

One captive black-capped Capuchin monkey (Cebus apella) that died suddenly, found in cage probably 24 hours after the death, presented characteristics compatible with leptospirosis such as jaundice and friable and haemorrhagic kidney at postmortem examination.

\section{Clinical samples and culture}

Kidney and urine samples were collected and maintained frozen for $72 \mathrm{~h}$ until examined. Kidney suspension $(0.2 \mathrm{~mL})$ and one $\mathrm{mL}$ of urine were cultured in Fletcher medium (Difco) containing $10 \%$ of inactivated rabbit serum and a mixture of 3\% L-asparagine, $1 \%$ $\mathrm{CaCl}_{2}-\mathrm{MgCl}_{2}, 1 \%$ sodium pyruvate and meat extract and peptone. Aditional tubes of medium containing selective agents as 5Fluorouracil and Nalidixic acid were also used. The cultures were incubated in aerobiosis at $30^{\circ} \mathrm{C}$ for 60 days $(3,4,9)$.

\section{Experimental inoculation}

Three males and recently weaned guinea pigs (Cavia porcellus) with $150 \mathrm{~g}$ of weight were inoculated with $0.2 \mathrm{~mL}$ of urine and $0.2 \mathrm{~mL}$ of kidney suspension, by intraperitonial route, and were euthanized on the eighth post-infection day. Liver and kidney suspension of the guinea pigs were also cultured and incubated in the same conditions above $(3,4,9)$.

\section{DNA extraction}

The urine and kidney samples were centrifuged at 13,000 $\mathrm{g}$ for 10 minutes. After that, $400 \mu$ of TE $(10 \mathrm{mM}$ Tris- $\mathrm{HCl}, 1 \mathrm{mMEDTA}$, $\mathrm{pH}$ 8.0) were added to the sediment, and stirred for 10 seconds in a vortex. The mixture was then centrifuged at $13,000 \mathrm{~g}$ for 5 minutes, and $200 \mu \mathrm{L}$ of TE were added to the sediment. For the extraction with proteinase $\mathrm{K}, 300 \mu \mathrm{L}$ of lysis buffer $(15 \mu \mathrm{L}$ proteinase $\mathrm{K} 20$ $\mathrm{mg} / \mathrm{mL}, 30 \mu \mathrm{L}$ dodecil sodium sulfate $10 \%, 60 \mu \mathrm{L}$ TNE $5 X(50 \mathrm{mM}$ Tris, $500 \mathrm{mM} \mathrm{NaCl}, 1 \mathrm{mM}$ EDTA pH 8.0) and $195 \mu \mathrm{L}$ of ultra pure water were added to the suspension. The mixture was incubated for 2 hours at $56^{\circ} \mathrm{C}$. Lisates were extracted with saturated phenol and phenol/chloroform/isoamilic alcohol (25:24:1). DNA was precipitaded and resuspended in $30 \mu \mathrm{L}$ of TE and kept at $-20^{\circ} \mathrm{C}$. The integrity of the DNA was assessed by electrophoresis in $1 \%$ agarose gel containing $0.5 \mu \mathrm{g} / \mathrm{ml}$ ethidium bromide $(5,8)$.

\section{Polymerase chain reaction (PCR)}

Amplification was performed according as Merien et al., 1992 (5). Specific primer pair targeting the 16S rRNA region from Leptospira interrogans serovar canicola were used: Lep 1: 5' GGC GGC GCG TCT TAA ACA TG 3'and Lep 2: 3' TTC CCC CCA TTG AGC AAG ATT 5'.
The reactions were performed in a final volume of $50 \mu \mathrm{L}$ at the following reagents: $10 \mathrm{mM}$ Tris- $\mathrm{HCl}, \mathrm{pH} 8.3,50 \mathrm{mM} \mathrm{KCl}, 50$ $\mathrm{mM} \mathrm{MgCl} 2,200 \mu \mathrm{M}$ dNTP, 10 pmol of each primer, $2.5 \mathrm{U}$ Taq DNA polymerase and $50 \mathrm{ng}$ template DNA.

Amplification mixture was incubated in a thermalcycler PTC200 DNA Engine. Samples were denatured at $95^{\circ} \mathrm{C}$ for 5 minutes and then submitted to 29 cycles of $1 \mathrm{~min}$ at $94^{\circ} \mathrm{C}, 1.5 \mathrm{~min}$ at $63^{\circ} \mathrm{C}$ and $2 \mathrm{~min}$ at $72^{\circ} \mathrm{C}$ with a further extension cycle of $10 \mathrm{~min}$ at $72^{\circ} \mathrm{C}$, Leptospira serovar canicola and water were used respectively as a positive and negative controls.

\section{Electrophoresis}

PCR products were run on $2 \%$ agarose gel with TBE $0.5 \mathrm{X}$ (0.045 M Tris-borate and 1mM EDTA, pH 8.0) running buffer. Gel was stained with $0.5 \mu \mathrm{g} / \mathrm{ml}$ ethidium bromide. Molecular sizes were determinated based on a 100 bp ladder molecular mass marker. Kodak Digital Science 1D Image Analysis software was used to estimate sizes.

\section{RESULTS}

Isolation of Leptospira spp was negative both in culture and experimental inoculation. Fig. 1 shows the results of the PCR amplification for the detection of Leptospira spp. Clinical samples showed a $330 \mathrm{pb}$ amplified fragment that corresponds to the Leptospira genus.

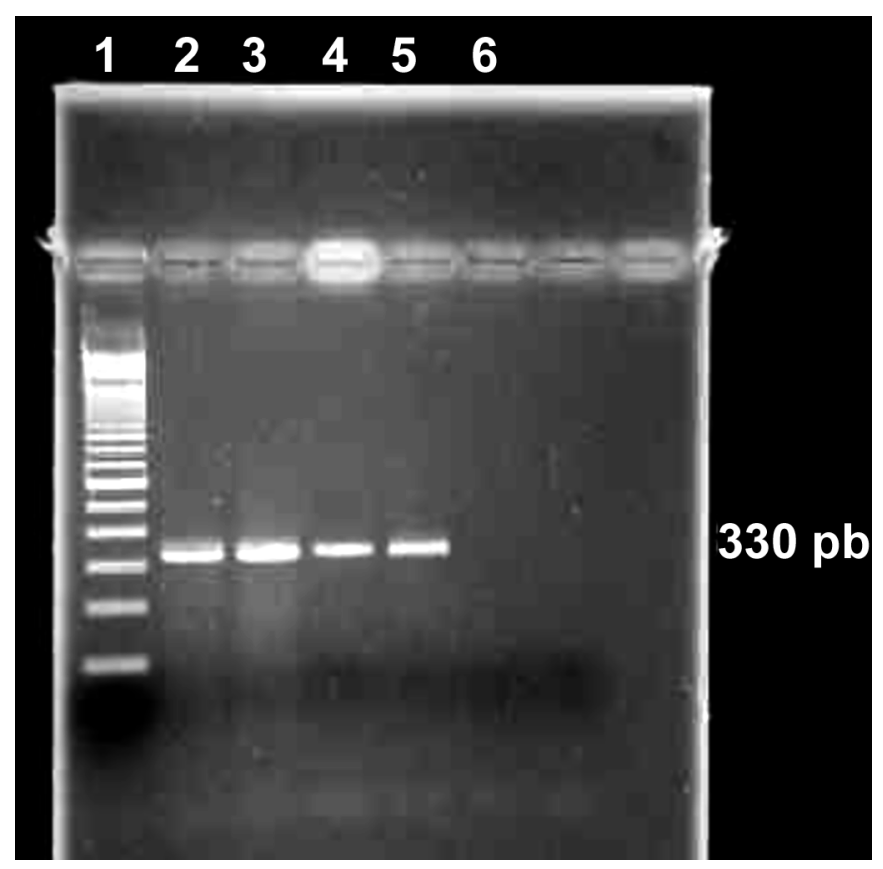

Figure 1. PCR technique used in clinical samples: 1- 100 pb DNA Ladder; 2- Urine; 3- Kidney; 4- Kidney (1:10); 5- Positive control (Leptospira interrogans serovar canicola); 6- Negative control. 


\section{DISCUSSION}

Leptospira has been recognized as an important human pathogen all over the world, and rat and other rodents are the most frequent sources to human infection. Monkeys can be natural carriers and pose a risk to other laboratory primates, to zoo animals, to the environment, and sometimes to the human being as an occupational disease $(3,4)$. In certain geographical areas, as Barbados, monkeys are common in an agricultural environment which favors the transmission to man. Barbadian monkeys are thus transmitting leptospiral infection among themselves independently of other groups of animals, but they are not a major source of human leptospirosis in that country (1).

Early diagnosis of human leptospirosis is always desirable, as the infection can run a fulminant course. Despite many studies are trying to find a more sensitive and specific, low cost, rapid and widely available diagnostic, MAT-microagglutination test and bacterial culture are still the standard methods. Other techniques as PCR can play an important role towards these goals. PCR has the potential to make a dramatic impact in diagnosing leptospirosis, because its high specificity and sensitivity, with capability of detecting as few as 10 microorganisms in a sample, and also is able to detect them during the first 10 days of the disease, before clinical expression or when it is confusing $(2,5)$.

Brown et al. (2) evaluated blood and urine samples from 71 patients with leptospirosis, which were examined by PCR, culture or serology. Samples from 44 (62\%) patients with the diagnosis of leptospirosis were positive by PCR as compared to 34 (48\%) by culture. The presence of leptospires was demonstrated by PCR in 13 patients before the development of antibodies, as well as in two patients who were seronegative during their illness and at autopsy. Samples from 16 patients without leptospirosis were seronegative and culture negative, and also negative by PCR.

Mérien et al. (6), compared polymerase chain reaction assay (PCR) amplifying a fragment of the Leptospira rrs gene and culture and microagglutination test (MAT) for the diagnosis of leptospirosis in a study of 200 patients with various clinical syndromes compatible with leptospirosis. In the first group of samples tested, PCR identified the 14 cases that later were unequivocally confirmed to be leptospirosis. Thirteen other systemic cases presenting decreasing leptospiral antibody titers were also detected by PCR. The average persistence of leptospiral DNA in serum was estimated at 12 days, with a maximum of 56 days in a culture-confirmed case.

In this case, as the monkey was found died probably 24 hours after the death occurred, the leptospire viability was affected by bad (autolyse) conservation and freezing, which prevented the isolation and the experimental inoculation from positive results. As the nonhuman primates present very few signs, PCR may be considered the most important direct method for leptospirosis in this case $(5,6,7,8)$.

This is the first report of PCR using as fundamental tool in the leptospirosis diagnosis of nonhuman primates.

\section{RESUMO}

\section{Detecção de Leptospira spp pela técnica da Reação da Polimerase em Cadeia (PCR) em amostras clínicas de macaco prego (Cebus apella) criado em cativeiro}

A leptospirose é uma zoonose de ampla distribuição geográfica que acomete os animais domésticos e silvestres, tendo o homem como ponto final da cadeia epidemiológica. O diagnóstico da leptospirose em primatas é dificultado em relação a outras espécies animais, porque os sinais clínicos e lesões são menos evidentes e a resposta de anticorpos é detectada apenas em curtos períodos. O presente trabalho tem por objetivo descrever a detecção de Leptospira spp empregando-se a Reação em Cadeia pela Polimerase (PCR) em amostras clínicas provenientes de um macaco prego (Cebus apella) criado em cativeiro, que apresentou ao exame macroscópico realizado durante a necrópsia, características sugestivas de leptospirose (icterícia e rins hemorrágicos). Amostras de urina e fragmento de rim friável foram submetidas às técnicas cultivo e inoculação experimental em cobaias e PCR empregando-se primers gênero específicos da sequiência do gene 16S rRNA de Leptospira interrogans sorovar canicola. Na PCR as amostras clínicas revelaram um fragmento amplificado de $330 \mathrm{pb}$ correspondente ao gênero Leptospira. $\mathrm{O}$ isolamento do agente foi negativo nas demais técnicas empregadas. Pelos resultados obtidos, verificase que a técnica de PCR representou uma importante ferramenta de detecção de leptospiras em primatas não-humanos, principalmente considerando-se que não foi necessária a viabilidade do patógeno, permitindo a detecção do agente em amostras autolisadas, congeladas ou amostras mal conservadas, que prejudicaram o isolamento e a inoculação experimental.

Palavras-chave: Leptospirose, primata não-humano, PCR, Cebus apella

\section{REFERENCES}

1. Baulu, J.; Everard, C.O.R.; Everard, J.D. Leptospires in vervet monkeys (Cercopithecus aethiops sabaeus) on Barbados. J. Wildl. Dis., 23(1): 60-66, 1987.

2. Brown, P.D.; Gravekamp, C.; Carrington, D.G.; Van of Kemp, H.; Hartskeerl, R.A.; Edwards, C.N.; Everard, C.O.R.; Terpstra, W.J.; Levett, P.N. Evaluation of the polymerase chain reaction goes early diagnosis of leptospirosis. Med. Microbiol., 43: 110-114, 1995.

3. Faine, S.; Adler, B.; Bolin, C.; Perolat, P. Leptospira and leptospirosis. Melbourne, MediSci, 2nd. ed., 1999: 121.

4. Faine, S. Leptospira and leptospirosis. CRC Press, Inc. USE. 1994: 222-234 
5. Mérien, F.; Amouriaux, P.; Perolat, P.; Baranton, G.; Sanint-Girons, T. Polymerase chain reaction goes detection of Leptospira spp in clinical samples. J. Clin. Microbiol., 30: 2219-2224, 1992.

6. Mérien, F.; Baranton, G.; Perolat, P. Comparison of polymerase chain reaction with microagglutination test and culture goes diagnosis of leptospirosis. J. Infect. Diseas., 172(4): 281-285, 1995.

7. Rebeca, P.; Dean, D. Overview of the epidemiology, microbiology, and pathogenis of Leptospira spp. in humans. Microb. Infect., 2: 1265-1276, 2000.

8. Richtzenhain, L.J.; Cortez, A.; Heinemann, M.B.; Soares, R.M.; Sakamoto, S.M.; Vasconcellos, S.A.; Higa, Z.M.M.; Scarcelli, E.;
Genovez, M.E. The multiplex PCR goes the detection of Brucella spp. and Leptospira spp. DNA FROM ABORTED BOVINE FETUSES. Vet. Microbiol., 87: 139-147, 2002.

9. Smith, C.R.; Ketterer, P.J.; Mcgowan, M.R.; Corney, B.G. The review of laboratory tecniques and their uses in the diagnosis of Leptospira interrogans serovar hardjo infection in cattle. Aust. Vet. J., 71(9): 290-294, 1994

10. Van Eys, G.J.J.M.; Gravekamp, C.; Gerritsen, M.J.; Quint, W.; Cornelissen, M.T.E.; Schegget, J.; Terpstra, W.J. Detection of leptospires in urinates by polymerase chain reaction. Journal of Clin. Microbiol., 27(10): 2258-2262, 1989. 